It will be apparent on reading the report that some of the recommendations made by the Commission are far-reaching and fundamental. It will also be clear that they have been made only after lengthy consideration and debate by an internationally picked group of enzymologists, themselves active workers in this branch of biochemistry. Despite this, however, the Council of the International Union of Biochemistry, and also the members of the Commission, fully realize that balanced and reasonable objections are likely to be raised to some, perhaps to many, of these recommendations. With this in mind, the Council of the Union, having accepted the report, decided to dissolve the existing Commission, and to set up as an interim measure a Standing Committee on Enzymes, composed of S. P. Colowick, A. L. Lehninger, O. Hoffmann-Ostenhof and E. C. Webb. The purpose of this Standing Committee is to receive criticisms, suggestions and comments on the report, to list any newly discovered enzymes with a view to allotting them a provisional name and place in the classified Table of Enzymes, and, in addition, to take up any new problem that may arise in this field. As an example, the Standing Committee is already at work on the problem of naming and numbering of iso-enzymes, a topic that is becoming of increasing interest to clinical biochemists. The report has also been passed to the International Commission of Editors of Biochemical Journals, which was set up by the International Union of Biochemistry in 1961 under the presidency of Dr. J. T. Edsall (Journal of Biological Chemistry). It is hoped that comments from national committees for biochemistry and from editorial committees and other interested organizations or persons will be sent, if possible before January 1, 1963, to Dr. E. C. Webb*, who has agreed to act as secretary of the Standing Committee. When these have been received, it is the intention of the Inter. national Union of Biochemistry to set up a second commission on enzymes in order to consider these comments and to incorporate changes where desirable in a second edition of the report, which, it is hoped, may then serve as a generally acceptable, definitive document covering the nomenclature of enzymes and coenzymes.

* Address until July 1962, Department of Biochemistry, Cambridge: and after that date, Department of Biochemistry, University of Queensland, Brisbane.

\title{
OBITUARIES
}

\section{Dr. A. F. Bruun}

Dr. Anton Frederick BruUn, the Danish marine zoologist and oceanographer, died suddenly on December 13, 1961, whilo speaking at a scientific meeting in Copenhagen. $\mathrm{He}$ would have been sixty on the following day, having been born on December 14, 1901, at Jelling, Jutland, where his people were farmers. While still a boy, Bruun contracted poliomyelitis, which left him partially paralysed on the left side of his body, but far from using this disability as a pretext for a sedentary career he seems to have regarded it as a challenge to be accepted and as a spur to the vigorous mental and physical activity which impressed everyone who came in contact with him. So, instead of preparing to become a farmer like his father, Bruun went first to Søro, one of Denmark's foremost schools, and thence to the University of Copenhagen. He graduated in 1926, and then became successively assistant in the Danish Commission of Fisheries and Marine Research 1927-33, in the Marine Biological Laboratory 1933-38, and in the Zoological Museum, Copenhagen, 1938-44 where he continued as a curator until 1958, when he became an assistant professor. These appointments were, in a way, the means used by Bruun to further his increasing oceanographical purposes, for his comprehensive approach demanded that he should get about and study the oceans of the world, visit marine biological laboratories and zoological institutions and know well those people with interests similar to his own. Thus from 1928 until 1930 he was with the Dana expedition around the world, and his association with Johannes Schmidt, the leader, undoubtedly influenced and enhanced Bruun's subsequent career. From 1938 until 1946 he was involved with the Carlsberg Foundation's Dana expeditions. He was leader of the Northern Insuline Laboratory's expedition to Tunis just before the Second World War, and immediately after the War was in charge of the Atlantide expedition to West Africa, during 1945-46.

All these activities were for Bruun merely the long apprenticeship for the major objective, a marine biological and oceanographical expedition, with wisely restricted general aims but with, as its principal purpose, an investigation of the physical and biological conditions in abyssal waters. The success of the achievements of the Galathea expedition is already acknowledged by oceanographers, but only those who knew Bruun can be aware of the amount of effort he put into the preparations which preceded the voyage. In all the activities connected with the expedition, the Galathea committee had the wisdom, informed experience and sound business sense of Bruun to draw on, and of course it was obvious from the start that he was the man to be leader.

This is not the place to give the details of Bruun's curriculum vitae, which can be found in the Danish Bla Bog ["Who's Who"]. It is sufficient to say that he served on very many committees concerned with natural science in general, and with its marine aspects in particular. Nationally and internationally his services were demanded and generously given, and they received recognition in fellowships of learned societies in various parts of the world-England, Scotland, New Zealand, Indonesia, India; with medals, awards or orders from his own country, Monaco, Japan, Sweden, the United States, Morocco, Tunis and the Philippines. With so much implication in administration and organizing affairs, it is remarkable that Bruun should have had any time for original work, yet he did produce a number of contributions from his research into marine zoology, of which his "Flying Fishes of the Atlantic" is an acknowledged monograph. He was also co-author of the narrative accounts of the Dana and Galathea expeditions and of a biography of Johannes Schmidt.

Bruun's outlook was comprehensive and international and he was at home in any country he visited. His linguistic capacity helped here, for in addition to his native Danish, he could understand and make himself clearly understood equally well in English, French and German and he was absorbingly interested in the vehicle of language as such. He was powerful in argument but liberal in his attention to the opposite point of view. 
With so much to absorb his attention it is surprising that Bruun found time to indulge in recreation of any kind, but he did it by extending his biological interests to botany and gardening. When at sea his cabin soon becamo filled with exotic plants, which he tended until they could be brought home. His garden was a great pleasure to himself and to his visitors, wealthy in its variety of shrubs and trees and in their association with places and people that he knew. His last letter to me contained a request for the name of a pear tree from which he had obtained a successful graft.

Bruun had a gentle, purposeful, stimulating onthusiasm which radiated to those around him. He was a happy man despite porsonal disability, illness and boreavoment. At sea he once said as we were moasuring and identifying fishes, "Well, we may not be great zoologists but no one can deny that we are enjoying ourselves". So far as his greatness is concerned there can be no doubt that his place is assured among the leaders of marine zoological research. His purpose held until he died, and this happoned as he would have wished, while discussing a thesis with his colleagues from the Galathea expedition and other marine zoologists on the distribution and origin of the abyssal fauna.

F. C. Fraskr

\section{Prof. Lester W. Sharp}

IT was a most fortunate coincidence that the period during which Dr. Lester W. Sharp devoted a lifetime of service to Cornell University as a distinguished professor of cytology included the years in which this long-established science becamo allied with the rapidly developing new scionces of genetics and cytogenotics. His contributions to this alliance as a teacher and investigator were indeed very significant.

Born at Saratoga, New York, April 21, 1887, Dr. Sharp moved at an early age with his family to Alma, Michigan, and completed his undergraduate training at Alma College in 1908. After spending the next two years in graduate study at Johns Hopkins University he transferred to Chicago, where he specialized in plant morphology and received a Ph.D. in 1912. The following year was spent in travel abroad and six months of study with Prof. Victor Grégoire in the University of Louvain.

Dr. Sharp joinod the staff of the Department of Botany in the College of Agriculture in Cornell University as an instructor in 1914, the year following the formation of the Department and the appointment of Prof. K. M. Wiegand as head. Promoted to an assistant professorship in 1915 and a professorship in 1920 , Sharp served continuously until his retire ment in 1947 after thirty-three years of distinguished service to the University. Shortly thereafter ho moved to Nuevo, California, where he lived in quiet retirement with Mrs. Sharp, adjoining the home of his sister, until his death on July 17, 1961.

Soon after going to Cornell, Dr. Sharp organized one of the first courses in plant cytology to be offered in an American university. His Introduction to Cytology, published in 1921, was the first American text-book of cytology with primary emphasis on the plant cell. Considered the standard toxt-book of plant cytology for many years, numerous editions were printed and a German translation was issued in 1931. Sharp's F'undamentals of Cytology was written in 1943 primarily for use as an olementary text, and a Spanish edition was published from Buenos Aires in 1947. In addition to his text-books Sharp was the author of numerous scientific papers on embryogeny, spermatogenesis and chromosome structure in plants.

Prof. Sharp's excellent reputation as a toacher was based on an extraordinary grasp of the literature of cytology and the new science of cytogenetics at a timo when rapid growth was taking place in these fields. His critical evaluation of new contributions was based on a broad background of knowledge in his own and related fields. Sharp's lectures and publications were models of orderly arrangement and of lucid, concise presentation, reflecting meticulous care in their preparation.

During his active scientific career, Prof. Sharp's influence stimulated many promising young scientists to concentrate their efforts in the broad fields of cytogenetics, whero their brilliant researches have contributed substantially to the spectacular progress which has been and is continuing to be achieved in this field.

L. F. RaNDOLPH

\section{Dr. John Bartholomew, C.B.E.}

To geographers and cartographers the name Bartholomew is indeed a household word, for the family havo been map-makers of distinction for more than a hundred years. The name goes on and the work continues, but with the recent death of the fifth in the family line, John Bartholomow, an out. standing Scot, passes from the stage he graced in so many ways and despite, latterly, the severe handicaps of failing health.

He was educated at Morchiston Castle School, Edinburgh, and received specialist training at the University of Leipzig and the Sorbonne to fit him for the inevitable cartographer's carecr. In the First World War he served with the Gordon Highlanders and won the M.C. At the termination of hostilities he completed his arts degree at Edinburgh, and in 1920, on the death of his father, found himself with the entire responsibility of John Bartholomew and Son on his shoulders. He completed The Times Survey Atlas commenced by his father, and started a long line of atlases, which blazed a now trail in meeting the ever. growing needs of schools and universities, the business man and the layman. New projections were devisod to meet more adequately new demands, colour layering became a most artistic adjunct to science and no new technique to clarify lettering and legend was overlooked. Pcrmanence was sought in now inks and new paper, essential for documents to withstand wide changes in tomperature and humidity. In 1921 he was appointed cartographer to H.M. King George V.

The list of publications under Bartholomew's direction is a most impressive one, yot he found time to serve in other fields dear to his heart. He played a largo part in the founding of the chair of gcography in tho University of Edinburgh and in securing for the Department adequate library and Iaboratory facilities. He was joint honorary secretary of the Royal Scottish Geographical Society for thirty years and then occupied the presidential chair for four. $\mathrm{He}$ was a most active member of the lixecutive Committee of the National Trust for Scotland.

His university awarded him an honorary LL.D. in 1956, the Royal Scottish Geographical Society its Gold Modal in 1954, and tho Royal Geographical Society its Founder's Medal "for distinguished service to cartography" in 1961, the year after he receivod his C.B.E.
D. A. Allas 